\title{
Cytidine 5'-Diphosphate Reductase and Thymidine Kinase Activities in Phytohemagglutinin-stimulated Lymphocytes of Normal Subjects of Various Ages and Patients with Immunodeficiency
}

\author{
EIJI TAKEDA, ${ }^{(32)}$ YASUHIRO KURODA, TOSHIYUKI WATANABE, MICHINORI ITO, \\ ETSUO NAITO, TAKANORI SEKIGUCHI, TAKAO ICHIOKA, TEIZO HOSODA, AND \\ MASUHIDE MIYAO \\ Department of Pediatrics, School of Medicine, Tokushima University, Kuramoto-Cho 3, \\ Tokushima City, Tokushima, Japan
}

\begin{abstract}
Summary
The activities of CDP reductase and thymidine kinase in $10^{6}$ to $5 \times 10^{6}$ phytohemagglutinin (PHA)-stimulated lymphocytes isolated from 2 to $5 \mathrm{ml}$ of peripheral blood of individual subjects were measured. The activities of $\mathrm{CDP}$ reductase $\left(\mathrm{pmol} / \mathrm{h} / \mathbf{1 0}^{7}\right.$ cells) and thymidine kinase ( $\mathrm{nmol} / \mathrm{h} / \mathbf{1 0}^{7}$ cells) were high in infants, $698 \pm 307$ and $64.2 \pm 20.2$, constant in subjects of 1-40 years old, $401 \pm 181$ and $38.1 \pm 15.3$, and low in persons of more than 80 years old, $121 \pm 113$ and $22.3 \pm 17.8$, respectively. The ratio of thymidine kinase to CDP reductase activity increased with age, indicating that dependency on the salvage pathway of DNA synthesis in lymphocytes increased with age. The activities of CDP reductase and thymidine kinase were reduced in patients with the hyperimmunoglobulin $\mathbf{E}$ syndrome, congenital cytomegalovirus infection, anhidrotic ectodermal dysplasia with hyperimmunoglobulin A, Bloom's syndrome, immunodeficiency with hyperimmunoglobulinemia, and Down's syndrome. The clinical symptoms of these diseases seem to be due to impaired DNA synthesis of PHA-stimulated lymphocytes, but the degrees of reduction of enzyme activities were generally greater than that of thymidine incorporation in these patients.
\end{abstract}

\section{Abbreviations}

PHA, phytohemagglutinin

HEPES, 4-(2-hydroxyethyl)-1-piperazineethanesulfonic acid

Ribonucleotide reductase and thymidine kinase are thought to be rate-limiting enzymes in the de novo and salvage pathways, respectively, of DNA biosynthesis. Since the activities of these enzymes have been shown to be increased in rapidly proliferating tissues, such as tumors $(8,24,28)$, developing organs $(8,12,16)$, and regenerating liver $(15,28)$, it has been thought that these activities closely reflect the rate of DNA synthesis $(25,28)$.

Deficiencies of adenosine deaminase and purine nucleoside phosphorylase are observed in severe combined immunodeficiency. Immunodeficiency is thought to be due to inhibition of ribonucleotide reductase by the accumulation of deoxyadenosine triphosphate in adenosine deaminase deficiency (6) and deoxyguanosine triphosphate in purine nucleoside phosphorylase deficiency (5), because both deoxynucleotides are strong inhibitors of mammalian ribonucleotide reductase (9). From these consid- erations, ribonucleotide reductase activity in lymphocytes may closely reflect the manifestation of immunity.

On stimulation by PHA, lymphocytes are transformed into cells showing enhanced DNA synthesis and consequently increased thymidine incorporation into DNA. Thymidine kinase catalyzes the first and rate-limiting step from thymidine to DNA in this pathway. Since measurement of $\left[{ }^{3} \mathrm{H}\right]$ thymidine incorporation is reported not to be a precise assay of cell proliferation (2), measurements of ribonucleotide reductase and thymidine kinase activities should indicate better whether immunodeficiency and various other diseases are attributable to impaired DNA synthesis. These enzymes are difficult to assay in normal tissues because their activities are so low (25), but their activities are considerably increased in PHA-stimulated lymphocytes (18, 27). This paper reports studies on the ontogenic patterns of change in activities of these enzymes, involved in the de novo and salvage pathway, respectively, in PHA-stimulated lymphocytes from individual subjects and the relationship between the enzyme activities and thymidine incorporation, as a measure of the overall capacity of the salvage pathway, in children with immunodeficient diseases.

\section{MATERIALS AND METHODS}

Chemicals. CDP, ATP, thymidine, dithioerythritol, HEPES, snake venom (Crotalus adamanteus) and Dowex-1 (chloride form) were purchased from Sigma Chemical Co. (St. Louis, MO). ${ }^{14} \mathrm{C}$-labeled CDP and thymidine, and PCS II were obtained from the Radiochemical Centre (Amersham, England). Ficoll-Paque was from Pharmacia Fine Chemicals (Uppsala, Sweden), PHA from Wellcome, RPMI 1640 medium from M. A. Bioproducts (Walkersville, MD) and DEAE-cellulose paper (Whatman DE81) from Whatman Co. (Clifton, $\mathrm{NJ}$ ). All other reagents, which were of the highest grade available, were purchased from Wako Pure Chemical Co. (Tokyo, Japan).

Assay Methods. The following standard methods were used, unless otherwise stated. Lymphocytes from 2 to $5 \mathrm{ml}$ of peripheral blood were isolated by centrifugation on a Ficoll-Paque gradient. They were then washed twice and cultured at a density of $1 \times 10^{6}$ cells $/ \mathrm{ml}$ in RPMI 1640 medium with $10 \%$ fetal calf serum containing $1 \mu \mathrm{g} / \mathrm{ml}$ of PHA for $48 \mathrm{~h}$ at $37^{\circ} \mathrm{C}$ in a humidified atmosphere of $5 \% \mathrm{CO}_{2}$ in air. They were divided into three groups. Two groups were collected by centrifugation at $1500 \mathrm{rpm}$ 
for $10 \mathrm{~min}$ and suspended, respectively, in $50 \mu \mathrm{l}$ of $50 \mathrm{mM}$ HEPES buffer, pH 7.5, for CDP reductase assay and in $50 \mathrm{~mm}$ Tris- $\mathrm{HCl}$ buffer, $\mathrm{pH} 7.5$, with $5 \mathrm{~mm} \mathrm{KCl}$ for thymidine kinase assay. They were stored at $-70^{\circ} \mathrm{C}$ until use. CDP reductase (EC $1 \cdot 17 \cdot 4 \cdot 1)$ was assayed by the method of Steeper and Steuart (23), as modified by Takeda and Weber (24), and thymidine kinase (EC 2.7.1.21) was assayed by the method of Weber et al. (28), with modification for the conditions required for PHAstimulated lymphocytes. The medium for assay of CDP reduction consisted of $33 \mathrm{~mm}$ HEPES buffer, $\mathrm{pH} 7.5,10 \mathrm{~mm}$ dithioerythritol, $8 \mathrm{mM}$ Mg-acetate, $4 \mathrm{mM}$ ATP, $0.025 \mathrm{mM} \mathrm{FeCl}_{3}, 0.1$ $\mathrm{mM}{ }^{14} \mathrm{C}$-labeled CDP $(6 \mu \mathrm{Ci} / \mu \mathrm{mol})$ and $1 \times 10^{6}$ to $5 \times 10^{6}$ cells. The incubation mixture for thymidine kinase assay consisted of $50 \mathrm{~mm}$ Tris- $\mathrm{HCl}$ buffer, $\mathrm{pH} 7.5,5 \mathrm{~mm}$ ATP, $2.5 \mathrm{~mm} \mathrm{MgCl}_{2}, 1$ $\mathrm{mm}\left[2-{ }^{14} \mathrm{C}\right]$ thymidine $(1 \mu \mathrm{Ci} / \mu \mathrm{mol})$, and cells. For study of thymidine incorporation, one group of viable lymphocytes that had been cultured for $48 \mathrm{~h}$ was pulsed with $0.05 \mu \mathrm{Ci}$ of $\left[{ }^{14} \mathrm{C}\right]$ thymidine $/ 10^{6}$ cells. The cells were collected after 2 to $24 \mathrm{~h}$ by centrifugation at $1500 \mathrm{rpm}$ for $10 \mathrm{~min}$ and the medium was discarded. The cells were washed three times with saline, suspended in $1 \mathrm{ml}$ of distilled water, and stored at $-70^{\circ} \mathrm{C}$. Radioactivity was determined in a liquid scintillation counter after addition of $5 \mathrm{ml}$ of PCS II.

Statistical Analysis. Student's $t$ test was employed to calculate the significance of differences.

\section{RESULTS}

Development of Assays for Ribonucleotide Reductase and Thymidine Kinase Activities in Small Amounts of PHA-stimulated Lymphocytes. The optimum assay conditions were found to be as described in "Materials and Methods." CDP reductase in PHA-stimulated lymphocytes was similar to that in other mammalian cells in that ATP and dithioerythritol were absolute requirements. The CDP reductase and thymidine kinase activities in unstimulated lymphocytes were $7.5 \pm 0.1 \mathrm{pmol} / \mathrm{h} / 10^{7}$ cells and $1.8 \pm 0.6 \mathrm{nmol} / \mathrm{h} / 10^{7}$ cells, respectively, although in practice, more than $10^{8}$ lymphocytes were required to obtain a reliable value for CDP reductase activity. Maximal increases in activity were observed when the culture medium contained $0.3-$ $3 \mu \mathrm{g} / \mathrm{ml}$ of PHA. As shown in Figure 1, the CDP reductase and thymidine kinase activities in PHA-stimulated lymphocytes increased 4-fold and 2-fold, respectively, in $24 \mathrm{~h}$ and reached maxima in $48 \mathrm{~h}$, which were maintained until $72 \mathrm{~h}$. Both activities decreased to $50-60 \%$ of the maximum by day 6 of

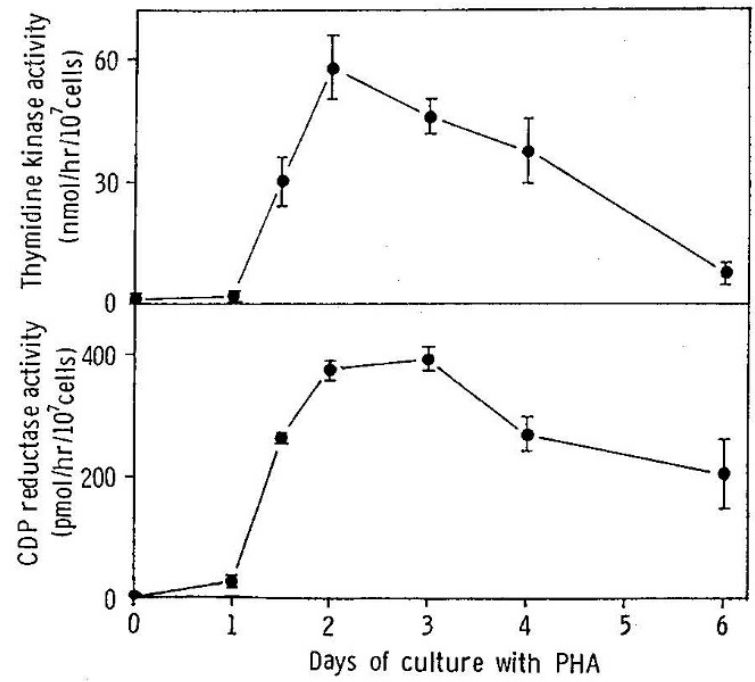

Fig. 1. CDP reductase and thymidine kinase activities during transformation of human lymphocytes. Lymphocytes from the same individual were cultured for the indicated times with phytohemagglutinin. Enzyme activities were determined as described in "Materials and Methods." Points and bars are mean \pm SD from triplicate determinations. culture. Under the present conditions, the reactions were linear for $60 \mathrm{~min}$ with $1 \times 10^{6}$ to $5 \times 10^{6}$ lymphocytes.

CDP Reductase Activity, Thymidine Kinase Activity, and the Ratio of the Two Activities in Subjects of Different Ages. As shown in Figure 2, CDP reductase activity in lymphocytes from infants was significantly higher than that in cells from older persons, was similar in cells of subjects of 1 to 40 years old, and was markedly reduced in persons of over 80 years old. Relatively wide variations were found in the CDP reductase activities of different normal persons, but the standard deviations of CDP reductase and thymidine kinase activities in the same subjects were 7.9 and $14.5 \%$, respectively. Thus, the values were reproducible in repeat experiments and the lowest activities in different age groups of up to 40 years old were almost the same.

Thymidine kinase activity in different age groups showed a pattern of change similar to that of CDP reductase activity, but its maximum activity in each group was 2- to 3.5 -fold the minimum activity, whereas that of CDP reductase was 4- to 8fold the minimum activity. The minimum activity of thymidine kinase was highest in infants, constant in subjects of 1 to 40 years, and greatly reduced in persons over 80 years old.

The ratio of thymidine kinase to CDP reductase activity increased with age, and the ratios in groups over 7 years old were significantly higher than that of infants (Fig. 3). This age-related increase was very marked in aged persons.

CDP Reductase and Thymidine Kinase Activities in Various Diseases. The enzyme activities were measured in individual patients with growth and immunological disturbances to determine whether the symptoms were due to impaired DNA synthesis. The CDP reductase and thymidine kinase activities were both decreased in patients with the hyperimmunoglobulin $E$ syndrome, congenital cytomegalovirus infection, anhidrotic ectodermal dysplasia with hyperimmunoglobulin A, Bloom's syndrome, and immunodeficiency with hyperimmunoglobulinemia (Table 1) and in 7 of 17 patients with Down's syndrome. No disease in which only one enzyme activity was reduced was observed. The ratio of thymidine kinase to CDP reductase activity tended to be high in patients with reduced enzyme activities, particularly in those with congenital cytomegalovirus infection and immunodeficiency with hyperimmunoglobulinemia (Table 1). Both activities were normal in milk allergy, xeroderma pigmentosum, and Cockayne's syndrome. The activities were also not decreased in endocrine diseases (pituitary dwarfism, adrenogenital syndrome, cretinism, and hyperthyroidism), congenital metabolic disorders (adrenoleukodystrophy, histidinemia, ornithine carbamoyltransferase deficiency, Wilson's disease, and Morquio's syndrome), congenital heart disease, progressive muscular dystrophy, or Turner's syndrome.

Rates of Thymidine Incorporation in Normal Subjects and Patients with Reduced Activities of CDP Reductase and Thymidine kinase. Thymidine incorporation into lymphocytes of normal subjects after 48-h incubation with PHA increased with time to a maximum of $6 \mathrm{~h}$, as shown in Figure 4 . Thymidine incorporation into lymphocytes from patients with low enzyme activities, such as those with congenital cytomegalovirus infection and immunodeficiency with hyperimmunoglobulinemia, was also linear for $6 \mathrm{~h}$, but then continued to increase. This indicates that the thymidine incorporation rate should be determined in a period of within $6 \mathrm{~h}$ for identification of patients with impaired DNA synthesis. The thymidine incorporation rates in $2 \mathrm{~h}$ by cells from patients with reduced activities were lower than those by normal cells (Table 1). It is noteworthy that in these patients the reduction of enzyme activities, and particularly CDP reductase activity, were greater than that of thymidine incorporation.

\section{DISCUSSION}

It has been observed (22) that the pool size of deoxynucleotide in mammalian cells is small and supports DNA synthesis for only a short time. Assays of ribonucleotide reductase and thy- 

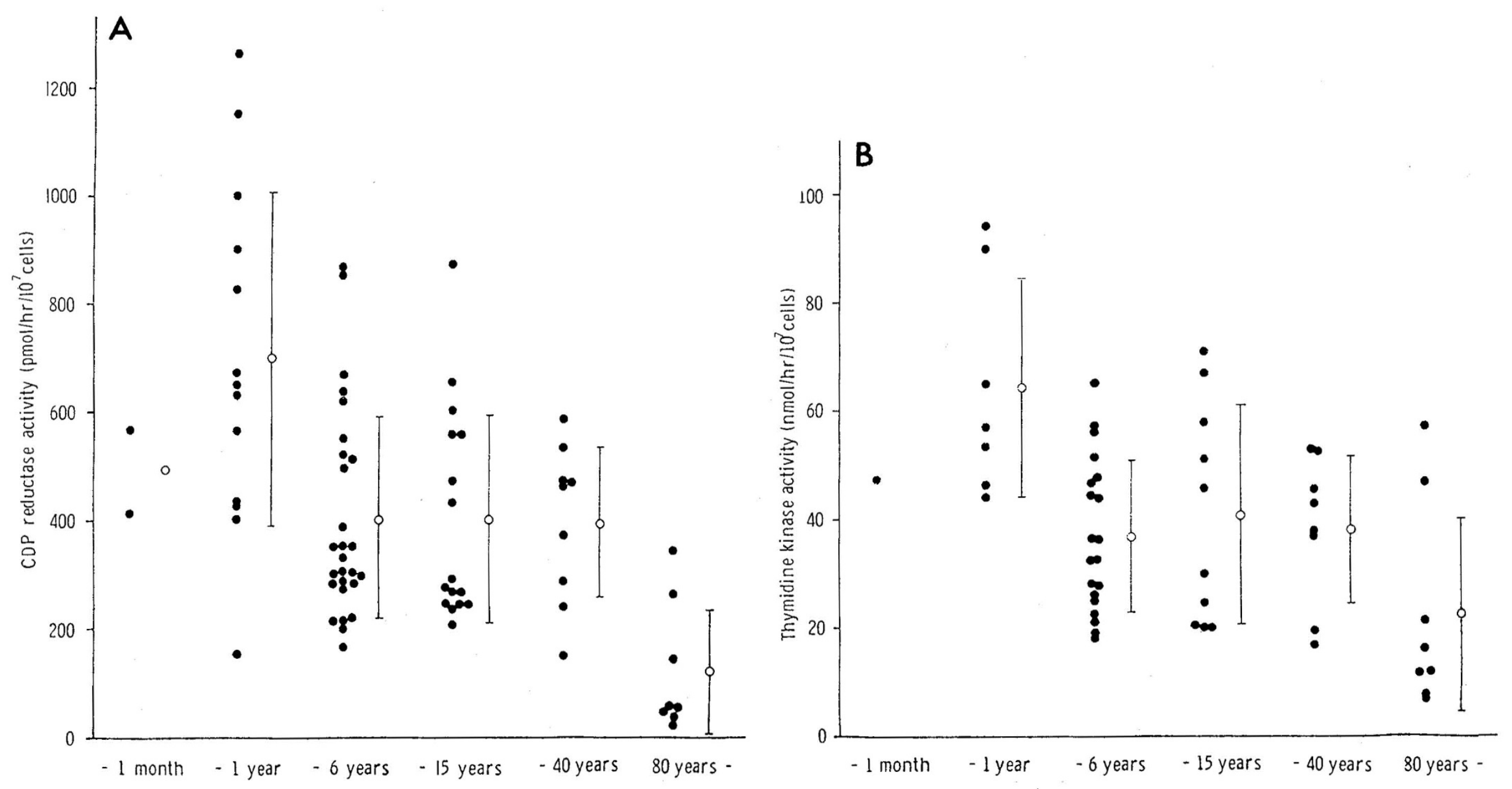

Fig. 2. A, CDP reductase activity ( $\mathrm{pmol} / \mathrm{h} / 10^{7}$ cells) in PHA-stimulated lymphocytes from normal subjects of different ages. The means $\pm \mathrm{SD}$ (ranges) for the groups of $<1$ year, $1-6$ years, $6-15$ years, $15-40$ years, and $>80$ years were: $698 \pm 307$ (155-1260), $402 \pm 189$ (165-869), $402 \pm 191$ (207-872), $395 \pm 137$ (145-584) and $121 \pm 113$ (20-344), respectively. The value for the group of $<1$ year was significantly different from those for the groups of $1-6$ years $(P<0.01), 6-15$ years $(P<0.01), 15-40$ years $(P<0.01)$, and $>80$ years $(P<0.001)$. That of the group of $>80$ years was also significantly different from those for the groups of $<1$ year $(P<0.001), 1-6$ years $(P<0.001), 6-15$ years $(P<0.01)$, and $15-40$ years $(P<0.001) . B$, thymidine kinase activity (nmol/h/107 cells) in PHA-stimulated lymphocytes from normal subjects of different ages. The means $\pm \mathrm{SD}$ (ranges) for the groups of $<1$ year, 1-6 years, 6-15 years, 15-40 years, and $>80$ years were: $64.2 \pm 20.2$ (44.0$94.1), 36.9 \pm 13.9(18.2-65.1), 40.7 \pm 20.1(19.9-70.6), 37.9 \pm 13.5(16.9-52.6)$, and $22.3 \pm 17.8(6.5-57.1)$, respectively. The value for the group of $<1$ year was significantly different from those for the groups of $1-6$ years $(P<0.001), 6-15$ years $(P<0.05), 15-40$ years $(P<0.02)$, and $>80$ years $(P<0.01)$. That of the group of $>80$ years was also significantly different from those for the groups of $<1$ year $(P<0.01)$ and $1-6$ years $(P<0.05)$. 


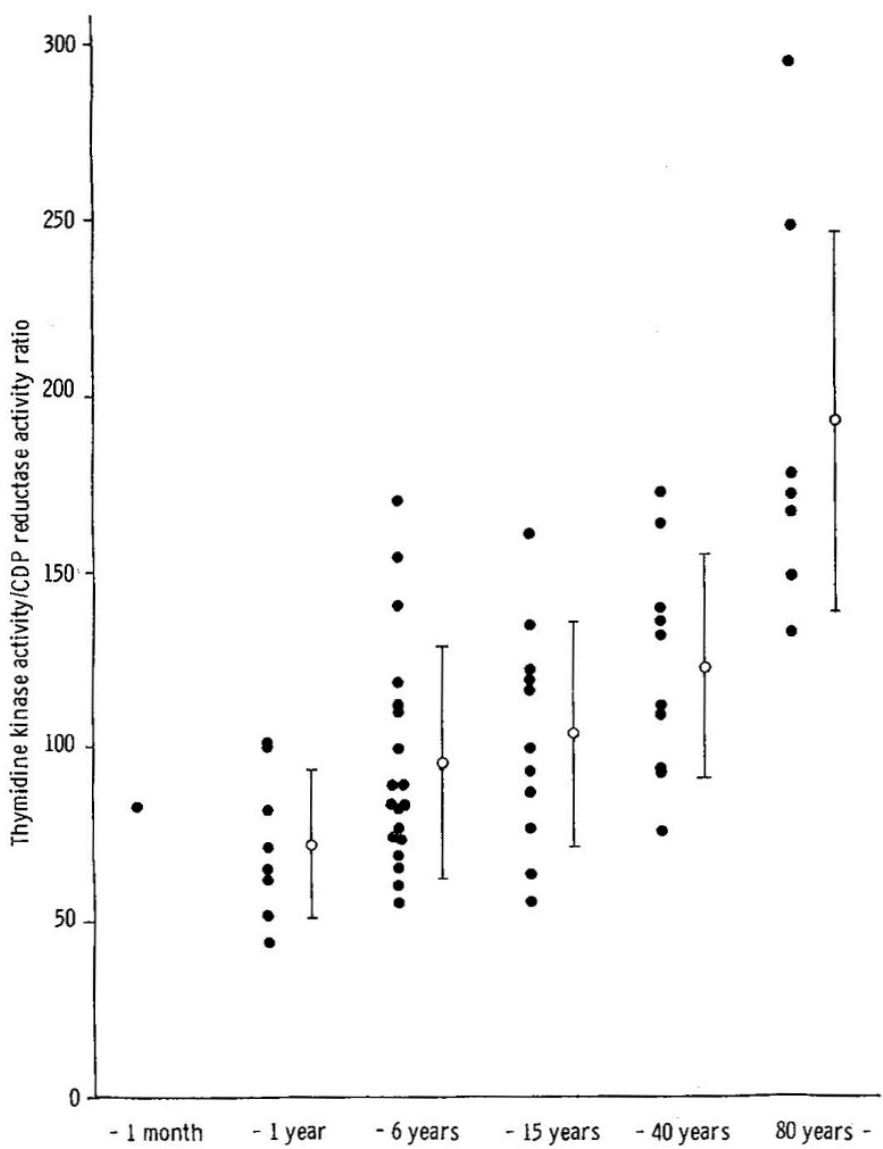

Fig. 3. Ratios of thymidine kinase to CDP reductase activity in different age groups. The mean $\pm \mathrm{SD}$ (ranges) for the groups of $<1$ year, 1-6 years, $6-15$ years, $15-40$ years, and $>80$ years were: $72 \pm 21(44-101)$, $95 \pm 33(55-170), 103 \pm 32(55-160), 122 \pm 32(75-172)$, and $191 \pm 54$ (132-590), respectively. The value for the group of $<1$ year was significantly different from those for the groups of 6-15 years $(P<0.05), 15-$ 40 years $(P<0.01)$, and $>80$ years $(P<0.001)$. That of the group of $>80$ years was also significantly different from those for the groups of $<1$ year $(P<0.001), 1-6$ years $(P<0.001), 6-15$ years $(P<0.001)$ and $15-40$ years $(P<0.01)$.

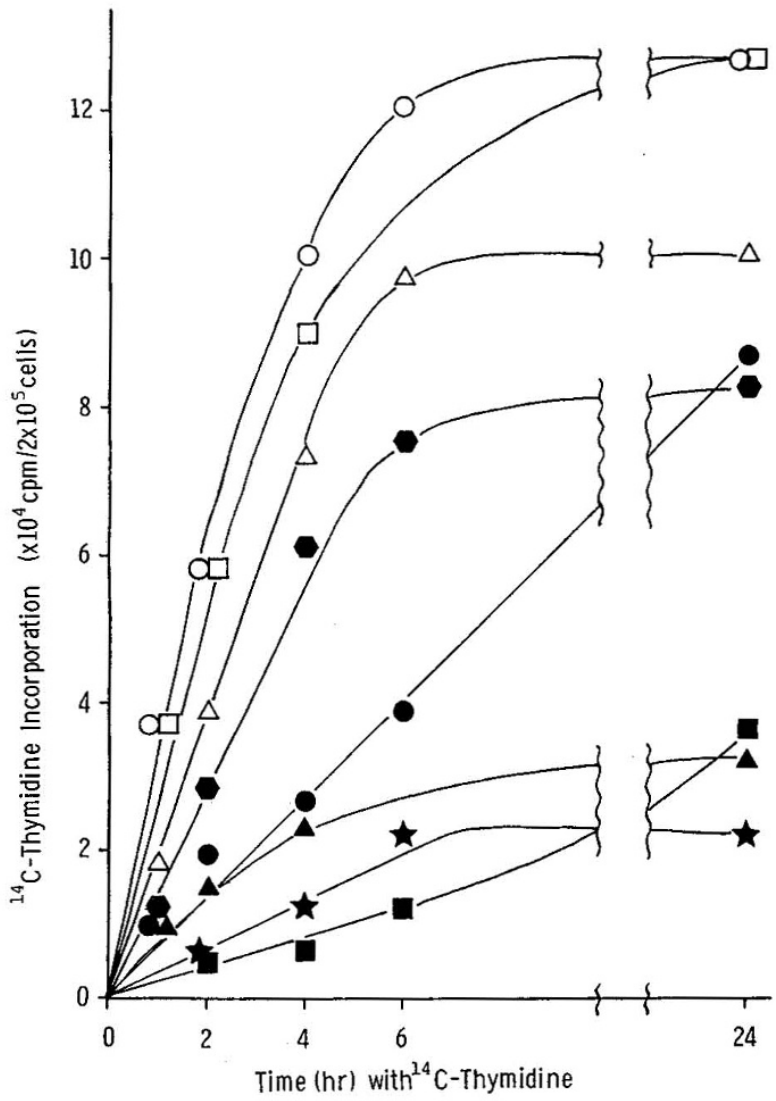

Fig. 4. Relationship between thymidine incorporation and time of incubation with $\left[{ }^{14} \mathrm{C}\right]$ thymidine. Cells were incubated for $48 \mathrm{~h}$ with PHA before experiments as described in "Materials and Methods." The means $\pm \mathrm{SD}$ of the activities of CDP reductase $\left(\mathrm{pmol} / \mathrm{h} / 10^{7}\right.$ cells) and thymidine kinase $\left(\mathrm{nmol} / \mathrm{h} / 10^{7}\right.$ cells) and thymidine incorporation in $2 \mathrm{~h}(\mathrm{cpm} / \mathrm{h} / 2$ $\times 10^{5}$ cells $)$ in normal subjects were $401 \pm 181(n=52), 38.1 \pm 15.3(n$ $=38)$, and 23,898 $\pm 5,021(n=21)$, respectively. Normal $(O, \square, \Delta)$, congenital cytomegalovirus infection (๑), anhidrotic ectodermal dysplasia with hyperimmunoglobulin $\mathrm{A}(\bullet)$, immunodeficiency with hyperimmunoglobulinemia $(\square)$, Bloom's syndrome $(\boldsymbol{\Delta})$, and hyperimmunoglobulin E syndrome $(\star)$.

Table 1. Activities of CDP reductase and thymidine kinase, the ratio of thymidine kinase to CDP reductase activity, and rates of $\left[{ }^{14} \mathrm{C}\right]$ thymidine incorporation in various immunodeficient diseases*

\begin{tabular}{|c|c|c|c|c|c|c|c|c|}
\hline & $\begin{array}{c}\text { CDP } \\
\text { reductase } \\
\text { activity } \\
\text { (pmol/h/10 } / 10^{7} \\
\text { cells) }\end{array}$ & $\begin{array}{c}\% \text { of } \\
\text { mean in } \\
\text { normal } \\
\text { subjects }\end{array}$ & $\begin{array}{c}\text { Thymidine } \\
\text { kinase } \\
\text { activity } \\
\text { (nmol/h/10 } / 10^{7} \\
\text { cells) }\end{array}$ & $\begin{array}{c}\% \text { of } \\
\text { mean in } \\
\text { normal } \\
\text { subjects }\end{array}$ & $\begin{array}{c}\text { Ratio of } \\
\text { thymidine kinase } \\
\text { to CDP reductase } \\
\text { activity }\end{array}$ & $\begin{array}{c}\% \text { of } \\
\text { mean in } \\
\text { normals }\end{array}$ & $\begin{array}{c}{\left[{ }^{14} \mathrm{C}\right] \text { Thymidine }} \\
\text { incorporation } \\
\left(\mathrm{cpm} / \mathrm{h} / 2 \times 10^{5}\right. \\
\text { cells) }\end{array}$ & $\begin{array}{c}\% \text { of } \\
\text { mean in } \\
\text { normal } \\
\text { subjects }\end{array}$ \\
\hline $\begin{array}{l}\text { Hyperimmunoglobulin E syn- } \\
\text { drome }\end{array}$ & $102 \pm 13(4)$ & 25 & $14.3 \pm 1.4(4)$ & 38 & $140 \pm 11(4)$ & 147 & $9,076 \pm 163(2)$ & 38 \\
\hline $\begin{array}{l}\text { Congenital cytomegalovirus in- } \\
\text { fection }\end{array}$ & $71 \pm 29(2)$ & 10 & $9.1 \pm 0.7(2)$ & 14 & $144 \pm 49(2)$ & 200 & $10,125 \pm 584(2)$ & 42 \\
\hline $\begin{array}{l}\text { Anhidrotic ectodermal dyspla- } \\
\text { sia with hyperimmunoglobu- } \\
\text { lin A }\end{array}$ & $61 \pm 25(4)$ & 15 & $7.6 \pm 3.9(4)$ & 20 & $139 \pm 20(4)$ & 146 & $13,707 \pm 2,334(3)$ & 57 \\
\hline Bloom's syndrome & $45 \pm 35(7)$ & 11 & $6.1 \pm 2.1(5)$ & 16 & $147 \pm 48(4)$ & 120 & $6,440 \pm 2,854(6)$ & 27 \\
\hline $\begin{array}{l}\text { Immunodeficiency with hyper- } \\
\text { immunoglobulinemia }\end{array}$ & $20(2)$ & 5 & $6.9 \pm 1.9(2)$ & 18 & $343 \pm 68(2)$ & 333 & $2,032 \pm 706(3)$ & 9 \\
\hline
\end{tabular}

* The mean value \pm SD (ranges) for thymidine incorporation in normal subjects was $23,898 \pm 5,021(17,037-35,669) \mathrm{cpm} / \mathrm{h} / 2 \times 10^{5} \mathrm{cells}$. Numbers in parentheses are numbers of repeat determinations in the same patient.

midine kinase activities are required to obtain reliable biochemical parameters of cell proliferation, which may reflect the capacities of humans for growth and immunity.

Tyrsted et al. (27) reported that more than $1.8 \times 10^{7}$ PHA- stimulated lymphocytes were required to measure CDP reductase activity. However, by determining the optimal conditions, we developed a micromethod in which the activity could be determined using $10^{6}$ to $5 \times 10^{6}$ lymphocytes obtained from $2-5 \mathrm{ml}$ 
of peripheral blood. On 48-h culture of the cells with $1 \mu \mathrm{g} / \mathrm{ml}$ of PHA, when the cells from both young and aged subjects were only first generation metaphase cells (26), the activities of CDP reductase and thymidine kinase both reached maxima. Although peripheral lymphocytes of normal children showed a wide range of activities after $48 \mathrm{~h}$ of PHA stimulation, these activities were fairly reproducible and repeated tests on individuals gave similar results.

The CDP reductase and thymidine kinase activities of human lymphocytes are both higher in infants than in older subjects (Figure 2). Thus, the rate of DNA synthesis in T-lymphocytes is higher in infancy. Lymphocyte transformation in response to respiratory syncytial virus is significant in patients of 6 months of age or younger (21). Lymphocytes from newborn babies react more than those from adults to nonspecific stimulations with mitogens, such as PHA and concanavalin A (4). Our results on enzyme activities are consistent with this finding of a high response of lymphocytes of infants. Cell-mediated immunity is known to show age-related decrease. It has generally been thought that the number of PHA-responsive cells in cultures in peripheral lymphocytes decreases as a function of the age of the donors $(10$, $11,19,29)$. The proliferation kinetics of PHA-stimulated lymphocytes from young individuals appeared to be relatively homogeneous when compared with that of an aged group (26). This might be explained by a difference in the mean cell cycle duration in cultures from young and aged subjects. We found that the CDP reductase and thymidine kinase activities of lymphocytes from subjects of 1-40 years old were constant, but that the activities were decreased in cells from persons of over 80 years old. Moreover, the ratio of thymidine kinase to CDP reductase activity in lymphocytes showed an age-related increase, especially in persons of over 80 years old. This indicates that the predominant pathway of DNA synthesis in transformed lymphocytes gradually alters from the de novo to the salvage pathway with age. These results suggest that the de novo pathway is more important than the salvage pathway for lymphocyte transformation, a possibility that was also supported by the findings of Bernheim et al. (2). These enzyme activities seem to be good parameters of the rate of DNA synthesis, because their correlations with thymidine incorporation were 0.8788 (CDP reductase) and 0.8535 (thymidine kinase) in normal controls. However, the kinetic patterns of thymidine incorporation in patients with reduced enzyme activities were not consistent after pulse labeling with thymidine for $6 \mathrm{~h}$. The thymidine incorporation rate in $2 \mathrm{~h}$ by cells from these patients was lower than normal (Table 1). Therefore, the results indicated that diseases with low enzyme activities might be due to impairment of DNA synthesis in lymphocytes. It has been reported that the diseases listed in Table 1 involve impaired cell-mediated immunity $(3,7,13,14,17,20)$. In addition, the degrees of reduction of enzyme activities were greater than that of thymidine incorporation in these patients. This absence of a parallel between the enzyme activities and thymidine incorporation is very interesting and indicates that aberrant immune function is a manifestation of a defect in enzyme induction. Thus, a dissociation between thymidine incorporation and enzyme activities might be observed when DNA synthesis in lymphocytes is impaired to various degrees. A dissociation of thymidine incorporation and DNA polymerase activity has also been observed in human PHA-stimulated lymphocytes after x-ray irradiation (1).

An alternative explanation for the discrepancies between the enzyme activities and $\left[{ }^{3} \mathrm{H}\right]$ thymidine incorporation is that the assay of cell proliferation by thymidine incorporation is not accurate. Consistent with this idea, it has been reported that the value of (cpm incorporated/number of $S$ phase cells) varied when assayed in PHA-stimulated lymphocyte cultures after 2 -h $\left[{ }^{3} \mathrm{H}\right]$ thymidine pulses on successive days (2). This variation was attributed to change in the rate of thymidine transport, endogenous thymidine synthesis, or DNA replication.
The ratio of thymidine kinase to CDP reductase activity tended to be high in patients with reduced enzyme activities. The ratio was particularly high in cases of congenital cytomegalovirus infection and immunodeficiency with hyperimmunoglobulinemia that showed aberrant kinetics of thymidine incorporation after 6-h exposure to thymidine. These results suggest that the salvage pathway of DNA synthesis predominates in lymphocytes with reduced activities. These enzyme activities did not reflect ability for DNA repair, because they were normal in patients with xeroderma pigmentosum and Cockayne's syndrome. It is particularly interesting that results suggested the existence of a defect in the DNA biosynthetic system as well as the DNA repair system in Bloom's syndrome. No abnormalities in enzyme activities were found in patients with endocrine diseases or various diseases with growth disturbance. It is concluded from the present work that the assay of both enzyme activities is a very useful and sensitive method for diagnosis of lymphocyte dysfunction due to a defect in DNA synthesis and that it may have a different significance from assay of thymidine incorporation.

\section{REFERENCES AND NOTES}

1. Agarwal SS, Brown DQ, Katz ET, Loeb.LA 1977 Screening for deficits in DNA repair by the response of irradiated human lymphocytes to phytohemagglutinin. Cancer Res 37:3594

2. Bernheim JL, Dorian R, Mendelsohn J 1977 Pitfalls in the lymphocyte proliferation assay: variation in proliferation kinetics and cold thymidine pools. In: Lucas DO (ed) Regulatory Mechanism in Lymphocyte Activation. Academic Press, New York, p 464

3. Booss J, Wheelock EF 1977 Progressive inhibition of T-cell function preceding clinical signs of cytomegalovirus infection in mice. J Infect Dis 135:478

4. Carr MC, Stites DP, Fudenberg HH 1972 Cellular immune aspects of the human fetal-maternal relationship. I. In vitro response of cord blood lymphocytes to phytohemagglutinin. Cell Immunol 5:21

5. Cohen A, Gudas LJ, Amman AJ, Staal GE, Martin DW Jr 1978 Deoxyguanosine triphosphate as a possible toxic metabolite in the immunodeficiency associated with purine nucleoside phosphorylase deficiency. J Clin Invest 62:1404

6. Cohen A, Hirschhorn R, Horowitz SD, Rubinstein A, Polmar SH, Hong R Martin DW Jr 1978 Deoxyadenosine triphosphate as a potentially toxic metabolite in adenosine deaminase deficiency. Proc Natl Acad Sci USA 75:472

7. Davis JR, Solomon LM 1976 Cellular immunodeficiency in anhidrotic ectodermal dysplasia. Acta Dermatol 56:115

8. Elford HL 1972 Functional regulation of mammalian ribonucleotide reductase. Adv Enzyme Regul 10:19

9. Eriksson S, Thelander L, Ákerman M 1979 Allosteric regulation of calf thymus ribonucleotide diphosphate reductase. Biochemistry 18:2948

10. Ford BSI, Adams Y, Yamaguchi Y, Litwin A 1974 Phytomitogen response of peripheral blood lymphocytes in young and older subjects. Clin Exp Immunol 17:657

11. Hallgren HM, Buckley CE, Gilbertson VA, Yunis EJ 1973 Lymphocyte phytohemagglutinin responsiveness, immunoglobulin and autoantibodies in aging humans. J Immunol 111:1101

12. Herzfeld A, Raper SM, Gore I 1980 The ontogeny of thymidine kinase in tissues of man and rat. Pediatr Res 14:1304

13. Hill HR 1982 The syndrome of hyperimmunoglobulinemia $E$ and recurrent infections. Am J Dis Child 136:767

14. Hütteroth TH, Litwin SD, German J 1975 Abnormal immune responses of Bloom's syndrome lymphocytes in vitro. J Clin Invest 56:1

15. Larsson A, Neilands JB 1966 Significance of ribonucleotide reduction in the biosynthesis of the deoxyribose moiety of regenerating rat liver deoxyribonucleic acid. Biochem Biophys Res Commun 25:222

16. Machovich R, Greengard O 1972 Thymidine kinase in rat tissues during growth and differentiation. Biochim Biophys Acta 286:375

17. Melamed J, Rubinstein A, Kadish A, Manabe T, Santorineou M, Einhorn A 1978 Impairment of cell-mediated immunity in ectodermal dysplasia with aplastic anemia. Helv Paediatr Acta 33:169

18. Munch-Peterson B, Tyrsted G 1977 Induction of thymidine kinases in phytohemagglutinin-stimulated human lymphocytes. Biochim Biophys Acta 478:364

19. Pisciotta AV, Westring DW, DePrey C, Walsh B 1967 Mitogenic effect of phytohemagglutinin at different ages. Nature (Lond) 215:193

20. Saxon A, Kobayashi RH, Stevens RH, Singer AD, Stiehm ER, Siegel S 1980 In vitro analysis of humoral immunity in antibody deficiency with normal immunoglobulins. Clin Immunol Immunopathol 17:235

21. Scott R, Kaul A, Sott M, Chiba Y, Ogra PL 1978 Development of in vitro correlates of cell-mediated immunity to respiratory syncytial virus infection in humans. J Infect Dis 137:810

22. Skoog KL, Bjursell KG, Nordenskjöld BA 1974 Cellular deoxynucleotide triphosphate pool levels and DNA synthesis. Adv Enzyme Regul 12:345 
23. Steeper JR, Steuart CD 1981 A rapid assay for CDP reductase activity in mammalian cell extracts. Anal Biochem 34:123

24. Takeda E, Weber G 1981 Role of ribonucleotide reductase in expression of the neoplastic program. Life Sci 28:1007

25. Therander L, Reichard P 1979 Reduction of ribonucleotides. Annu Rev Biochem 48:133

26. Tice RR, Schneider EL, Kram D, Thorne P 1979 Cytokinetic analysis of the impaired proliferation responses of peripheral lymphocytes from aged humans to phytohemagglutinin. J Exp Med 149:1029

27. Tyrsted G, Gamulin V 1979 Cytidine $5^{\prime}$-diphosphate reductase activity in phytohemagglutinin stimulated human lymphocytes. Nucleic Acids Res 6:305
28. Weber G, Shiotani T, Kizaki H, Tzeng D, Williams JC, Gladstone N 1978 Biochemical strategy of the genome as expressed in regulation of pyrimidine metabolism. Adv Enzyme Regul 16:3

29. Weksler ME, Hutterroth TH 1974 Impaired lymphocyte function in aged humans. J Clin Invest 53:99

30. Informed consent was obtained for the families of all subjects in this study.

31. This work was supported by Grant 57770636 from the Ministry of Education, Science, and Culture of Japan.

32. Requests for reprints should be addressed to Dr. Eiji Takeda, Department of Pediatrics, Tokushima University, School of Medicine, Tokushima, Japan.

33. Received for publication February 1, 1984.

\title{
Bilirubin Photooxidation Products in the Urine of Jaundiced Neonates Receiving Phototherapy
}

\author{
DAVID A. LIGHTNER, ${ }^{(26)}$ WILLIAM P. LINNANE III, AND CHARLES E. AHLFORS \\ Department of Chemistry, University of Nevada, Reno, Nevada, USA and Section of Neonatology, Department of \\ Pediatrics, School of Medicine, University of California at Davis, Davis, California, USA
}

\begin{abstract}
Summary
Bilirubin-IX $\alpha$ photooxidation products were detected by high performance liquid chromatography in the urine of neonates undergoing phototherapy for hyperbilirubinemia. The in vivo photoproducts were identified by chromatographic comparison with authentic synthetic standards using two complementary methods. Bilirubin photooxidation products were not detected in urine from jaundiced infants not receiving phototherapy. The specific photoproducts identified in the urine include propentdyopents, hematinic acid imide and its hydrolysis product (3-carboxy-2-methyl-2-hexenedioic acid), and the hydrolysis product (2-vinyl-3-methyl-maleic acid) of methylvinylmaleimide. Their total urinary concentrations were low $(0.2-0.9 \mathrm{mg} / \mathrm{dl})$ during phototherapy. These observations show that photooxidation of bilirubin clearly does occur during phototherapy. They are consistent with the view that, although photooxidation is not the major photochemical event associated with phototherapy, it can and clearly does occur concurrently with photoisomerization.
\end{abstract}

\section{Abbreviations}

UCB, unconjugated $(4 Z, 15 Z)$-bilirubin-IX $\alpha$

HPLC, high performance liquid chromatography

Phototherapy is used routinely in hospitals for treating neonatal jaundice (hyperbilirubinemia). Patients are irradiated with white or blue light to enhance elimination of the yellow cytotoxic metabolite $(4 Z, 15 Z)$-bilirubin-IX $\alpha$, which is produced in copious quantities in mammals by degradation of heme (2). Under normal metabolic conditions, UCB is detoxified by conjugation in the liver and excreted in bile. When conjugation is impaired, UCB accumulates in plasma and partitions into extravascular tissues, including the brain (23). About 150,000 infants per year in the United States develop plasma UCB levels of $15 \mathrm{mg} / \mathrm{dl}$ (3), and a large number of these receive some form of treatment (phototherapy) to remove or accelerate the excretion of UCB from the body, apparently reducing the risk of bilirubin encephalopathy (23).

The mechanism of UCB elimination in jaundice phototherapy has been investigated for many years. At first it was thought that the important photochemical event was accelerated catabolism of UCB to water-soluble derivatives that were excreted principally in bile and, to some extent, in urine (18). In this connection, a considerable effort was directed toward studies of bilirubin photooxidation $(7,21)$, wherein singlet oxygen, i.e. molecular oxygen in its first electronic excited state and known to be cytotoxic (25), was thought to be the oxidizing species (7). Recent data indicate that singlet oxygen may not be implicated and that bilirubin photooxidation may proceed via radical intermediates (6). Mechanistic questions aside, the products of in vitro photooxidation have been well characterized (7).

The widely held belief that bilirubin photodegradation is the responsible mechanism for lowering serum UCB in neonatal phototherapy (5) began to erode with the discovery of an apparent augmented excretion of UCB in the bile of Gunn rats (19) and jaundiced babies (10) undergoing light irradiation. This important finding was extremely intriguing because UCB normally cannot be excreted by the liver unless it is converted to polar conjugates, principally glucuronides (2). To accommodate the confirmed $(11,21)$ biliary excretion, $Z \rightleftarrows E$ photochemical configurational isomerization at the meso carbon-carbon double bonds of $(4 Z, 15 Z)$-bilirubin-IX $\alpha$ was proposed $(7,8)$ to give more polar $\boldsymbol{E}$-isomers, isomers that could more easily cross the liver. The hypothesis was subsequently tested (15) and confirmed in Gunn rats $(12,24)$. More recently, the structures of the $\boldsymbol{E}$ isomers have been proved, and it has been shown that these isomers are formed in jaundiced rats exposed to blue light and in humans during phototherapy $(14,16)$. At present, current evidence favors the photochemical configurational isomerization of UCB (to $E$-isomers) as one of the most rapidly occurring photochemical events in phototherapy.

Of what importance is UCB photodegradation, however? In early studies with Gunn rats, Ostrow (20) suggested that UCB 